\title{
NASOPHARYNGEAL COLONIZATION BY HAEMOPHILUS INFLUENZAE IN CHILDREN ATTENDING DAY-CARE CENTERS, IN RIBEIRÃO PRETO, STATE OF SÃO PAULO, BRAZIL
}

\author{
Maria E.N. Bonifácio da Silva ${ }^{1}$; Paulo da Silva²; Marta I.C. Medeiros²; Suzel N. Neme²; ${ }^{2}$ Claudia Macedo ${ }^{3}$; \\ José Moacir Marin ${ }^{4 *}$
}

${ }^{1}$ Laboratório de Análises Clínicas, Faculdade de Ciências Farmacêuticas de Ribeirão Preto, Universidade de São Paulo, Ribeirão Preto, SP, Brasil; ${ }^{2}$ Secção de Bacteriologia, Laboratório de Ribeirão Preto, Instituto Adolfo Lutz, Secretaria da Saúde de São Paulo, Ribeirão Preto, SP, Brasil; ${ }^{3}$ Departamento de Genética, Faculdade de Medicina de Ribeirão Preto, Universidade de São Paulo, Ribeirão Preto, SP, Brasil; ${ }^{4}$ Departamento de Morfologia, Estomatologia e Fisiologia, Faculdade de Odontologia de Ribeirão Preto, Universidade de São Paulo, Ribeirão Preto, SP, Brasil.

Submitted: June 23, 2004; Approved: September 27, 2004

\begin{abstract}
Nasopharyngeal carriage of Haemophilus influenzae (Hi) was studied in 114 healthy children < 3 years old, attending day-care centers (DCCs) in Ribeirão Preto, State of São Paulo, Brazil. Biotype, serotype (by specific antisera and PCR) and antibiotic susceptibility to 14 antibiotics of each isolate were determined. Carriage rates of $H i$ were $72.0 \%$. Isolates belonged to biotype II (36.5\%), I (21.5\%), V (18.2\%) and III (16.1\%). The prevalence of encapsulated $\mathrm{Hi}$ carriers was $3.2 \%$ for type $\mathrm{f}, 1.0 \%$ for type b, $1.0 \%$ for type $\mathrm{d}$ and $1.0 \%$ for type e. Resistances to trimethoprim-sulphamethoxazole and ampicillin were $46.2 \%$ and $10.7 \%$ respectively. Multidrug resistance was found in $14(15.0 \%)$ of the isolates tested. Among the isolates, $13.9 \%$ were $\beta$-lactamase producers; there were no $\beta$-lactamase negative ampicillin resistant isolates. DCCs are niches with a high potential for the spread of microorganisms and should be continuously monitored to detect elimination or replacement of $H$. influenzae type b colonization.
\end{abstract}

Key words: Haemophilus influenzae, day-care center, Hib colonization, Hib vaccination

\section{INTRODUCTION}

Haemophilus influenzae (Hi) is one of the major bacterial species causing infection in children. Strains of $H i$ are classified according to their polysaccharide capsule. There are six structurally and antigenically distinct capsular serotypes, designated from a to $\mathrm{f}$ (34). Encapsulated strains are responsible for a variety of invasive diseases, the most frequent being meningitis, but epiglottitis, arthritis, pneumonia and cellulites also occur (39).

Widespread use of $H$. influenzae capsular type b conjugate vaccine over the world has resulted in the virtual elimination of invasive $\mathrm{Hib}$ disease in countries that have included the vaccine in their infant immunization programs $(21,32)$. In Brazil, the program of immunization was started in the second semester in 1999, with apparently the same rate of success (36). With the decline in $\mathrm{Hib}$ disease, non type $\mathrm{b} H i$ has become a more important cause of $H i$ disease. Serotype $\mathrm{f}(\mathrm{Hif})$ is reported to be the most common cause of invasive encapsulated non-b $H i$ disease in children (41). Serotype a is a rare cause of pneumonia and meningitis (37).

Nonencapsulated, i.e. nontypable $\mathrm{Hi}(\mathrm{NTHi})$, strains are well recognized causes of sinusitis and otitis media in children (25). Some data suggest that NTHi are a significant cause of invasive diseases, such as pneumonia in children of developing countries (17). Although this pathogen is associated with a variety of infections, it is also frequently isolated from the upper respiratory tract of healthy children, with reported carrier rates of up to $60.0 \%(12,17,26)$.

*Corresponding Author. Mailing address: Departamento de Morfologia, Estomatologia e Fisiologia, Faculdade de Odontologia de Ribeirão Preto, Av. do Café S/N - Campus USP. 14040-904, Ribeirão Preto, SP, Brasil. Tel.: (+5516) 602-4035, Fax: (+5516) 633-0999, E-mail: jmmarin@rge.fmrp.usp.br 
Day care center (DCC) attendance has been reported as a major risk factor for increased rates of carriage of these respiratory bacterial pathogens (1), and for increased incidence of upper respiratory tract infection (4). Children attending DCCs carried potentially pathogenic bacteria such as $\mathrm{Hi}$ in the nasopharynx more often, and also had more frequently symptoms of upper respiratory tract infection (20).

Resistance to $\beta$-lactam antibiotics among $\mathrm{Hi}$ isolates has been increasing over the last few decades $(11,22)$. The main mechanism of resistance detected in wild type $H i$ strains, is the production of $\beta$-lactamase with an overall prevalence of $13.4 \%$ in Europe (15), and up to $41.6 \%$ in the United States (23). In Japan, the prevalence of $\beta$-lactamase production is low (13.9\%). In most cases, the mechanism for ampicillin resistance is the production of plasmid-mediated TEM or ROB $\beta$-lactamases, which are detected in $>30.0 \%$ of isolates in some countries $(11,22)$. It has been reported that children at DCC can be reservoirs for antibiotic-resistant bacteria (19).

In Japan, the prevalence of $\beta$-lactamase negative ampicillinresistant (BLNAR) strains is $28.8 \%$ (40), while in the United States and Europe this phenotype is rare $(<1.0 \%)(15,23)$. In Latin America (10) and in Brazil $(6,8)$, the prevalence of $\beta$ lactamase production is almost the same as that found in Europe, around 9.0-14.5\%, and BLNAR strains have not been detected.

The present study was designed to monitor nasopharyngeal carriage of $\mathrm{Hi}$ in healthy children attending DCCs in Ribeirão Preto, São Paulo State, Brazil and the resistance patterns of the isolates.

\section{MATERIALS AND METHODS}

\section{Study population}

From November 2002 to November 2003, boys and girls aged from 18-36 months attending municipal DCC in Ribeirão Preto, São Paulo State were recruited, and specimens collected. A total of 114 children attending three DCCs were enrolled in the study. DCCs were selected so as to represent the spectrum of social strata and different geographical areas in the city. Children were excluded from the study if they had taken antibiotics up to 1 week prior to the study and were considered adequately immunized against $\mathrm{Hib}$ if, prior to the study, they had received 3 doses of vaccine (at 2, 4 and 6 months of age). Only one swab for culture was obtained from each child on a single occasion.

The research protocol was approved by the Ethics Committee of the School of Dentistry of São Paulo University at Ribeirão Preto, and the study was initiated with the agreement of the Municipal Service of Health and Education of Ribeirão Preto and the approval of the DCC managers. Signed informed consent was obtained from a parent or guardian of each child and a questionnaire was completed with information regarding the subject's age, sex, family size, history of recent respiratory infection or antibiotic therapy.

\section{Sampling and cultures}

Nasopharyngeal samples were obtained from all children with a twisted applicator rayon tipped swab (Copan, Brescia, Italy) in Amies media without charcoal and plated on the same day on a selective medium of $10 \%$ sheep blood-chocolate brain heart infusion agar plates, supplemented with $300 \mathrm{mg} / \mathrm{L}$ bacitracin (Difco Laboratories, Detroit, USA). After overnight incubation under a $\mathrm{CO}_{2}$ - enriched atmosphere at $36^{\circ} \mathrm{C}$, plates were inspected for growth of $\mathrm{Hi}$. Isolates were identified by colony and cell morphology and by the demonstration of growth requirements for $\mathrm{V}$ and $\mathrm{X}$ factors. Strain biotype was further characterized by biochemical reactions (24). Capsular serotyping was performed by transferring $10 \mu \mathrm{L}$ of a milky suspension of the bacterial cells made in $0.85 \%$ formalinized saline to $10 \mu \mathrm{L}$ of the antiserum; all specific antisera (a to f antisera Difco, Detroit, MI) were run in parallel, and the slide was rocked for $1 \mathrm{~min}$. All strains were kept frozen at $-80^{\circ} \mathrm{C}$ in brain heart infusion broth (Difco, Detroit, MI) with glycerol (40\%) until further analysis.

\section{Antimicrobial susceptibility testing}

One colony from each primary culture was selected for further investigation. Susceptibility to amoxicillin - clavulanic acid (AMC-20/10 $\mu \mathrm{g}$ ), ampicillin (AMP-10 $\mu \mathrm{g}$ ), aztreonam_(ATM$30 \mu \mathrm{g}$ ), azithromycin (AZI-15 $\mu \mathrm{g}$ ), cefoxitin (CFO-30 $\mu \mathrm{g}$ ), ceftriaxone (CRO-30 $\mu \mathrm{g}$ ), ciprofloxacin (CIP-5 $\mu \mathrm{g}$ ), chloramphenicol (CLO-30 $\mu \mathrm{g}$ ), imipenem (IMI-10 $\mu \mathrm{g}$ ), levofloxacin (LVX-5 $\mu \mathrm{g}$ ), rifampin (RIF- $5 \mu \mathrm{g}$ ), trimethoprimsulphamethoxazole (TMP/SMX-25 $\mu \mathrm{g}$ ), tetracycline (TET-30 $\mu \mathrm{g}$ ) and ticarcillin-clavulanic acid (TIC 75/10 $\mu \mathrm{g}$ ) (CEFAR, São Paulo, Brasil) was determined by the disk diffusion method of Bauer and Kirby, using Mueller Hinton base (Difco, Detroit, MI), supplemented with $15 \mu \mathrm{g} / \mathrm{mL}$ of bovine hematin, $15 \mu \mathrm{g} / \mathrm{mL}$ of NAD (Sigma, St. Louis, USA) and $5 \mathrm{mg} / \mathrm{mL}$ of yeast extract (Difco, Detroit, MI), following the recommendations of the National Committee for Clinical Laboratory Standards (30). Hi ATCC 49247 and 49766 were included as quality control standards in each assay. The production of $\beta$-lactamase was determined by the chromogenic cephalosporin method (38) using reconstituted lyophilized nitrocefin (Glaxo 87/312, Glaxo Research, Unipath Ltd., Hamsphire, England). Hi ATCC 49247 was used as a negative control and Staphylococcus aureus ATCC 29213 was used as a positive control.

\section{DNA preparation}

Isolates were recovered from frozen storage by being subcultured on chocolate agar plates and incubated under 5\% $\mathrm{CO}_{2}$ at $36^{\circ} \mathrm{C}$ for $18 \mathrm{~h}$. High-molecular-weight chromosomal DNA was extracted from $\mathrm{Hi}$ isolates (33). Arapid DNA extraction method was also performed (27). 


\section{PCR}

Primers specific for the bexA gene (primers $\mathrm{H} 1$ and $\mathrm{H} 2$ ), required for capsular exports, were used to differentiate NTHi isolates from encapsulated isolates, in the 93 strains tested. Primers and PCR conditions used were as previously described $(13,27)$. Capsule typing was considered positive when DNA amplification of the bexA gene and one of the specific capsule genes occurred. Standard strains for all serotypes (ATCC 9006, ATCC 35533, ATCC 9007, ATCC 9332, ATCC 8142 and ATCC 9833) and a non-encapsulated strain (ATCC 49247) were used as positive controls for slide agglutination tests and PCR.

\section{RESULTS}

Between November 2002 to November 2003, 114 children $<3$ years of age, with the complete cycle ( 3 doses) of anti $\mathrm{Hib}$ immunization, attending three DCCs in Ribeirão Preto, were enrolled in this study.

$\mathrm{Hi}$ was isolated from a nasopharyngeal culture from 82 (72.0\%) of the 114 children and from a total of 93 of 114 samples (81.6\%). H. parainfluenzae were isolated from $2(1.7 \%)$ children and $H$. parahaemolyticus from $1(0.8 \%)$ child.

A total of 93 isolates were serotyped and biotyped. NTHi isolates were identified into seven biotypes, biotype II being the most common (36.5\%), followed by biotype I (21.5\%) (Table 1). Thirteen isolates (13.9\%) were $\beta$-lactamase-producing strains, and none were BLNAR (Table 1). Six isolates (6.4\%) were encapsulated, three belonged to serotype f (3.2\%), one belonged to serotype $\mathrm{b}(1.0 \%)$, one to serotype $\mathrm{d}(1.0 \%)$ and one to serotype e (1.0\%).

Antibiotic susceptibility analysis showed that 43 (46.2\%) of the isolates were resistant to trimethoprim-sulphamethoxazole (TMP-SMX), $10(10.7 \%)$ to ampicilin, and $4(4.3 \%)$ to ceftriaxone (Table 2). Resistance to both ampicillin and chloramphenicol was not found in any isolate. Forty five isolates $(48.3 \%)$ were susceptible to all the antibiotics tested. Multidrug resistance,

Table 1. Distribution of biotypes and $\beta$-lactamase positive strains of Haemophilus influenzae isolated from the nasopharynx of healthy children in day care centers in Ribeirão Preto, State of São Paulo, Brazil.

\begin{tabular}{ccc}
\hline Biotype & $\mathrm{N}^{\circ}$ of isolates $(\%)$ & $\beta$-lactamase positive (\%) \\
\hline I & $20(21.50)$ & $4(4.30)$ \\
II & $34(36.55)$ & $6(6.45)$ \\
III & $15(16.12)$ & 0 \\
IV & $4(4.30)$ & 0 \\
V & $17(18.27)$ & $2(2.15)$ \\
VII & $2(2.15)$ & $1(1.07)$ \\
VIII & $1(1.07)$ & 0 \\
\hline
\end{tabular}

Table 2. Antibiotic resistance rate of Haemophilus influenzae colonizing children attending day care centers in Ribeirão Preto, State of São Paulo, Brazil.

\begin{tabular}{cc}
\hline Antibiotic & $\mathrm{N}^{\circ}$ of isolates $(\%)$ \\
\hline Amoxicillin/clavulanic acid & 0 \\
Ampicillin & $10(10.75)$ \\
Azithromycin & $2(2.15)$ \\
Aztreonam & $2(2.15)$ \\
Cefoxitin & $3(3.22)$ \\
Ceftriaxone & $4(4.30)$ \\
Ciprofloxacin & 0 \\
Chloramphenicol & $3(3.22)$ \\
Imipenem & 0 \\
Levofloxacin & 0 \\
Rifampin & 0 \\
Trimethoprim/Sulphamethoxazole & $43(46.23)$ \\
Ticarcillin/clavulanic acid & 0 \\
\hline
\end{tabular}

defined as being resistant to two or more classes of antibiotics, was found in $14(15.0 \%)$ of the isolates tested. The most frequently identified pattern was resistance to ampicillin and TMP-SMX (9 isolates, 9.6\%).

\section{DISCUSSION}

Colonization of the human nasopharynx is the first step in the sequence of events resulting in $\mathrm{Hi}$ infections and disease. Previous studies have documented $H i$ point prevalence colonization rates among various populations to range from 11 to $88 \%(3,5,9,16,20,31)$ and most likely depending on differences in the children's hygiene practices, behavior, or antibiotic use. In this study of nasopharyngeal cultures from children $<3$ years old attending DCC in Ribeirão Preto- SP, the colonization rates are consistent with the variable rates reported. The increased carriage rates are most probably due to increased exposure resulting from crowding in the DCCs, this effect has been previously suggested to explain the higher carriage rates in children with more siblings $(20,28)$.

$\mathrm{Hi}$ isolates were distributed among seven biotypes with the exception of biotype VI (Table 1). The most common colonizing biotypes were type II, I, V and III agreeing exactly with the result of a previous study (5). Recently, in a few studies in DCC in which $H i$ biotypes were reported, one in Brazil (5), one in France (35) where the most common biotypes for $H i$ were type II (62.2\%), V (18.0\%) and I (16.2\%), and one in the USA (14), where the most common types were type II (37.0\%), III (21.0\%), I (13.0\%), V (12.0\%) matched the results of the present study. 
The studies in Brazil showed to involve Hib diseases, particularly meningitis, and in these cases the more commonly isolated biotypes were of types I and II (7).

After the introduction of Hib immunization in Brazil, type a has been proven to replace type $b$ as causative agent of meningitis (36). Surprisingly, in this study type a strains were not recovered from the children in day-care centers.

In DCCs studies, a small carriage rate of different serotypes has been found after Hib immunization; a French study with 1,683 healthy children reported $0.6 \%$ of type e and 0.4\% of type f (9); an American study with 198 children and 404 isolates, reported the isolation of only one serotype $f$ strain (14). In the present study three isolates (3.2\%) of serotype $\mathrm{f}$, one isolate of type $\mathrm{d}$ and one isolate of type e were found, a result not agreeing with the reported replacement (36); we have also found one isolate type b agreeing with a Dutch study (31) in which four isolates type b were found. Despite the success of the Hib vaccine, Hib isolates have not been fully eliminated. It is expected that $\mathrm{Hib}$ carriage will be maintained until the herd immunity levels become sufficient to avoid transmission; still, the risk of outbreaks of $\mathrm{Hib}$ disease even among fully vaccinated children in a DCC will continue to exist (29).

Young children attending DCCs have increased risk of more episodes of respiratory tract infections, including acute otitis media than children not attending DCC (2), this is reflected by the intensive use of antibiotics leading to increased resistance. Studies at DCCs in France, reported a high rate of $\beta$-lactamase positive strains $(44.5-60.0 \%)(9,35)$ compared with those of the general population (15). In the present study, the rate of $\beta$-lactamase positive strains detected at DCCs (13.9\%) was not different from those reported for the population $(6,8)$.

In a recent report on worldwide prevalence of antimicrobial resistance, $H i$ resistance to TMP-SMX showed considerable regional variability (14.0-31.0\% of isolates), highest rates being observed in Latin America (18), confirmed by the reported rates in Brazil 40.1- $45.2 \%$ (8), in this work we reported 46.2\% of TMPSMX resistance matching other rates reported in Brazil (8). Resistance to ampicillin reported in the present study was $10.7 \%$. In Brazil the combination of ampicillin and chloramphenicol is extensively applied because of its low cost and effectiveness (6); both antibiotics have been checked in two Brazilian studies on $\mathrm{Hi}$ antibiotic resistance, showing rates for ampicillin ranging from 10.0 to $13.8 \%(7,8)$, again agreeing with those presently reported.

Bacteria carried in the nasopharynx of normal children reflect the strains currently circulating in the community, causing respiratory infections; therefore, the study of the prevalence of these bacteria and of their resistance patterns can provide useful indications for more rational antibiotic therapy of these infections.
In summary, this study shows that widespread immunization with a Hib conjugate vaccine is associated with a significant reduction in the number of $\mathrm{Hib}$ nasopharyngeal carriers among $\mathrm{Hib}$ immunized children at DCCs, and despite the high use of antibiotics for young children treatment in Brazil, the rate of antibiotic resistance of the children attending DCC is not different from that of the general population. Nevertheless, DCC's should be continuously monitored to detect elimination or replacement of Hib colonization.

\section{ACKNOWLEDGEMENTS}

This work was supported by grant research 01/07595-2 from Fundação de Amparo a Pesquisa do Estado de São Paulo (FAPESP). Swabs were kindly provided by Copan, Italy. We thank the Ribeirão Preto Municipal Secretaries of Health and Education and also the managers of the day-care centers enrolled in this study. We thank Tania Marques for technical assistance and the parents and children who made this study possible.

\section{RESUMO}

\section{Colonização da nasofaringe por Haemophilus influenzae em crianças que freqüentam creches em Ribeirão Preto, Estado de São Paulo, Brasil}

A colonização da nasofaringe por Haemophilus influenzae (Hi) foi estudada em 114 crianças saudáveis com menos de 3 anos de idade e que freqüentam creches (day-care centers DCC) em Ribeirão Preto, estado de São Paulo, Brasil. Para cada uma das cepas isoladas foram determinados o biótipo, o sorotipo (por antisoro especifico e PCR) e a sensibilidade a 14 antibióticos. A frequiência de colonização por $\mathrm{Hi}$ foi de $72,0 \%$. As cepas isoladas foram identificadas como pertencentes aos biótipos II (36,5\%), I $(21,5 \%)$, V $(18,2 \%)$ e III $(16,1 \%)$. A frequiência encontrada de cepas encapsuladas foi de $3,2 \%$ para o tipo $\mathrm{f}$, $1,0 \%$ para o tipo b, $1,0 \%$ para o tipo d e $1,0 \%$ para o tipo e. A resistência para trimetoprim-sulfametoxazole e ampicilina foi de $46,2 \%$ e $10,7 \%$ respectivamente. Resistência múltipla foi encontrada em $14(15,0 \%)$ das cepas analisadas. 13,9\% das cepas analisadas eram produtoras de $\beta$-lactamase, e não foi recuperada nenhuma cepa $\beta$-lactamase negativa e ampicilina resistente. DCCs são considerados locais de risco, com um alto potencial de disseminação de microrganismos e por isto devem ser continuadamente monitorados com a finalidade de detectar a eliminação da colonização da nasofaringe por cepas $H$. influenzae tipo $b$ das crianças que freqüentam DCC, ou detectar a sua substituição por outro tipo de cepa.

Palavras-chave: Haemophilus influenzae, creches, colonização por $H i b$, antiHib vacinação 


\section{REFERENCES}

1. Akcakaya, N.; Torun, M.M.; Soylemez, Y. Incidence of Haemophilus influenzae in a day-care center .Turk J. Pediatr., 38, 289-293, 1996.

2. Alho, O.P.; Laaro, E.; Oja, H. Public health impact of various risk factors for acute otitis media in Northen Finland. Am. J. Epidemiol., 143, 1149-1156, 1996

3. Aniansson, G.; Alm, B.; Anderson, B.; Larsson, P.; Nylen, O.; Peterson, H.; Rigner, P.; Svanborg, M.; Svanborg, C. Nasopharyngeal colonization during the first year of life. J. Infect. Dis., 165, S38-42, 1992.

4. Berg, A.T.; Shapiro, E.D.; Capobianco, L.A. Group day care and the risk of serious infectious illnesses. Am. J. Epidemiol., 133,154-163, 1991.

5. Bonifacio da Silva, M.E.; Marin, J.M. An epidemiological study of Haemophilus influenzae at a Brazilian day care center. Braz. J. Infect. Dis., 5, 260-268, 2001.

6. Casagrande, S.T.; Vicente, E.J.; Landgraf, I.M.; Kobata, A.M.M. Antimicrobial resistance patterns of Haemophilus influenzae isolated from patients with meningitis in São Paulo, Brazil. Braz. J. Med. Biol. Res., 33, 295-300, 2000.

7. Casagrande, S.T.; Landgraf, I.M.; Kobata, A.M.M.; Zanella, R.C.; Bokerman, S. Antimicrobial resistance among invasive Haemophilus influenzae strains: results of a Brazilian study carried out from 1996 through 2000. Braz. J. Med. Biol. Res., 35, 1293-1300, 2002

8. Critchley, I.A.; Blosser, R.S.; Karlowsky, J.A.; Yamakita, J.; Barth, A.; Sader, H.S.; Mendes, C.; Teixeira, L.; Rossi, F.; Dias, C.A.C.; Jones, M.E.; Thornsberry, C.; Sahm, D.F. Antimicrobial resistance in respiratory pathogens isolated in Brazil during 1999-2000. Braz. J. Infect. Dis., 5, 294-304, 2001.

9. Dabernat, H.; Plisson-Saune, M.A.; Delmas, C.; Seguy, M.; Pelissier, R.; Faucon, G.; Bennamani, S.; Pasquier, C. Haemophilus influenzae carriage in children attending French day care centers: a molecular epimiological study. J. Clin. Microbiol., 41, 1664-1672, 2003.

10. De Andrade, A.L.; Brandileone, M.C.; DiFabio, J.L.; Oliveira, R.M.; Silva, S.A.; Baiocchi, S.S.; Martelli, C.M. Haemophilus influenzae resistance in Latin América: systematic review of surveillance data. Microb. Drug. Resist., 7, 403-411, 2001.

11. Doern, G.V.; Brueggemann, A.B.; Pierce, G.; Holley, H.P.; Rauch, A. Antibiotic resistance among clinical isolates of Haemophilus influenzae in the United States in 1994 and 1995 and detection of $\beta$ lactamase-positive strains resistant to amoxicillin-clavulanate: results of a national multicenter surveillance study. Antimicrob. Agents Chemother., 41, 292-297, 1997.

12. Faden, H.; Waz, M.J.; Bernstein, J.H.; Brodsky, L.; Stanierich, J.; Ogra, P.C. Nasopharyngeal flora in the first three years of life in normal and otitis prone children. Ann. Otol. Rhinol. Laryngol., 1000, 612-615, 1991.

13. Falla, T.J.; Crook, D.W.M.; Brophy, L.N.; Maskell, D.; Kroll, J.S.; Moxon, E.R. PCR for capsular typing of Haemophilus influenzae. J. Clin. Microbiol., 32, 382-386, 1994.

14. Farjo, R.S.; Foxman, B.; Patel, M.J.; Zhang, L.; Petigrew, M.M.; McCoy, S.I.; Marrs, C.F.; Gilsdorf, J.R. Diversity and sharing of Haemophilus influenzae strains colonizing healthy children attending day-care centers. Pediatr. Infect. Dis. J., 23, 41-46, 2004.

15. Felmingham, D.; Gruneberg, R.N. The Alexander Project 1996-197: latest susceptibility data from this international study of bacterial pathogens from community-acquired lower respiratory tract infections. J. Antimicrob. Chemother., 45, 191-203, 2000.

16. Forleo-Neto, E.; Oliveira, C.F.; Maluf, E.M.C.P.; Bataglin, C.; Araujo, J.M.R.; Kunz, L.F.; Pustai, H.K.; Vieira, V.S.D.; Zanella, R.C.; Brandileone, M.C.; Mimica, L.M.J.; Mimica, I.M. Decreased point prevalence of Haemophilus influenzae type b (Hib) oropharyngeal colonization by mass immunization of Brazilian children less than 5 years old with Hib polyribosylhibitol phosphate polysaccharide- tetanus toxoid conjugate vaccine in combination with diphtheriatetanus toxoids-pertussis vaccine. J. Infect. Dis., 180, 1153-1158, 1999.

17. Foxwell, A.R.; Kyd, J.M.; Cripps, A.W. Nontypeable Haemophilus influenzae: pathogenesis and prevention. Microbiol. Mol. Biol. Rev. 62, 294-308, 1998.

18. Holan, D.J.; Doern, G.V.; Fluit, A.C.; Roussel Devallez, M.; Jones, R.N. Worldwide prevalence of antimicrobial resistance in Streptococcus pneumoniae, Haemophilus influenzae and Moraxella catarrhalis in the SENTRY Antimicrobial Surveillance Program 1997-1999. Clin. Infect. Dis., 32(Suppl.), S81-93, 2001.

19. Holmes, S.J.; Marrow, A.L.; Pickering, L.K. Child-care practices: effects of social change on the epidemiology of infectious diseases and antibiotic resistance. Epidemiol. Rev., 18, 10-28, 1996.

20. Howard, A.J.; Dunkin, K.T.; Millar, G.W. Nasopharyngeal carriage and antibiotic resistance of Haemophilus influenzae in healthy children. Epidemiol. Infect., 100, 193-203, 1988.

21. Hviid, A.; Melbye, M. Impact of routine vaccination with a conjugate Haemophilus influenzae type b vaccine. Vaccine, 22, 378-382, 2004.

22. Jacobs, M.R.; Dayan, R.; Appelbaum, P.C.; Burch, D.J. Prevalence of antimicrobial-resistant pathogens in middle ear fluid: multinational study of 917 children with acute otitis media. Antimicrob. Agents Chemother., 42, 589-95, 1998.

23. Jacobs, M.R.; Bajaksouzian, S.; Zilles, A.; Lin, G.; Pankuch, G.A.; Appelbaum, P.C. Susceptibilities of Streptococcus pneumoniae and Haemophilus influenzae to 10 oral antimicrobial agents based on pharmacodynamic parameters: 1997 USA surveillance study. Antimicrob. Agents Chemother., 43, 1901-1908, 1999.

24. Kilian, M.; Biberstein, E.L. Genus Haemophilus. In: Krieg NR, Holt JG eds. Bergey's Manual of Systematic Bacteriology, Baltimore, Williams \& Wilkins, 1984

25. Klein, J.O. Role of nontypeable Haemophilus influenzae in pediatric respiratory tract infection. Pediatr. Infect. Dis., 16, 5-8, 1997.

26. Kuklinska, D.; Kilian, M. Relative proportions of Haemophilus influenzae in the throat of healthy children and adults. Eur. J. Clin. Microbiol., 3, 249-252, 1984.

27. LaClaire, L.L.; Tondella, M.L.C.; Beall, D.S.; Noble, C.A.; Raghunathan, P.L.; Rosenstein, N.E.; Popovic, T. Identification of Haemophilus influenzae serotypes by standard slide agglutination serotyping and PCR-based capsule typing. J. Clin. Microbiol., 41, 393-396, 2003.

28. Li, K.I.; Dashevsky, B.; Wal, E.R. Haemophilus influenzae type b colonization in household contacts of infected and colonized children enrolled in day care. Pediatrics, 78, 15-20, 1986.

29. McVernon, J.; Morgan, P.; Mallaghan, C.; Biswas, T.; Natarajan, M.; Griffiths, D.; Slack, M.; Moxon, R. Outbreak of Haemophilus influenzae type $\mathrm{b}$ disease among fully vaccinated children in a daycare center. Pediatr. Infect. Dis. J., 23, 38-41, 2004.

30. National Committee for Clinical Laboratory Standards. Performance standards for antimicrobial disk susceptibility test. Approved standard M2A8. Wayne, PA: National Committee for Clinical Laboratory Standards, 2003.

31. Peerbooms, P.G.M.; Engelen, M.N.; Stokman, D.A.J.; van Benthem, B.H.B.; van Weert, M.L.; Bruisten, S.M.; van Belkum, A.; Coutinho, R.A. Nasopharyngeal carriage of potential bacterial pathogens related to day care attendance, with special reference to the molecular epidemiology of Haemophilus influenzae. J. Clin. Microbiol., 40, 2832-2836, 2002.

32. Peltola, H. Worldwide Haemophilus influenzae type b disease at the beginning of the 21 st century: global analysis of the disease burden 25 years after the use of the polysaccharide vaccine and a decade after the advent of conjugates. Clin. Microbiol. Rev., 13, 302-317, 2000.

33. Pitcher, D.G.; Saunders, N.A.; Owen, R.J. Rapid extraction of bacterial genomic DNA with guanidine thiocyanate. Lett. Appl. Microbiol., 8, 151-156, 1989. 
34. Pittman, M. Variation and type specificity in the bacterial species Haemophilus influenzae. J. Exp. Med., 53, 471-495, 1931.

35. Raymond, J.; Armand-Lefevre, L.; Moulin, F.; Dabernat, H.; Commeau, A.; Gendrel, D.; Berche, P. Nasopharyngeal colonization by Haemophilus influenzae in children living in an orphanage. Pediatr. Infect. Dis. J., 20, 779-784, 2001.

36. Ribeiro, G.S.; Reis, J.N.; Cordeiro, S.M.; Lima, J.B.T.; Gouveia, E.L.; Petersen, M.; Salgado, K.; Silva, H.R.; Zanella, R.C.; Almeida, S.C.G.; Brandileone, M.; Reis, M.G.; Ko, A.I. Prevention of Haemophilus influenzae type b (Hib) meningitis and emergence of serotype replacement with type a strains after introduction of $\mathrm{Hib}$ immunization in Brazil. J. Infect. Dis., 187, 109-116, 2003.

37. Rutherford, G.W.; Wilfert, C.M. Invasive Haemophilus influenzae type a infections: a report of two cases and a review of the literature. Pediatr. Infect. Dis. J., 3, 575-577, 1984.
38. Sykes, R.B.; Mathew, M. Methods for detecting $\beta$-lactamase In: Reeves, D.S.; Phillips, J.D.; Williams, J.D.; Were, R. (Ed.). Laboratory Methods in Antimicrobial Chemotherapy. Churchill Livinstone, Edinburg, UK, p.64-69, 1978.

39. Turk, D.C.; May, J.R. Haemophilus influenzae. Its clinical importance. English University Pres, London, United Kingdom, 1967.

40. Ubukata, K.; Shibasaki, Y.; Yamamoto, K. Association of amino acid substitutions in penicillin-binding protein 3 with $\beta$-lactam resistance in $\beta$-lactamase-negative ampicillin resistant Haemophilus influenzae. Antimicrob. Agents Chemother., 45, 1693-1699, 2001.

41. Urwin, G.; Krohn J.A.; Deaver-Robinson, K.; Wenger, J.D.; Farley, M.M. Invasive disease due to Haemophilus influenzae serotype f: clinical and epidemiologic characteristics in the $H$. influenzae serotype b vaccine era. The Haemophilus influenzae Study Group. Clin. Infect. Dis., 22, 1069-1076, 1996. 